\title{
Debridement Effect on Periodontal Pathogen Porphyromonas gingivalis Cultured on Titanium by Application of Atmospheric-Pressure Plasma
}

\author{
Tadashi Miura $^{{ }^{*}}$, Masahiro Egawa ${ }^{2}$, Taichi Ito ${ }^{3}$, Toru Eguro ${ }^{4}$, Koji Tanabe $^{1,5}$, Masao Yoshinari ${ }^{1}$ \\ ${ }^{1}$ Oral Health Science Center, Tokyo Dental College, Tokyo, Japan \\ ${ }^{2}$ Department of Periodontology, Tokyo Dental College, Chiba, Japan \\ ${ }^{3}$ Department of Oral and Maxillofacial Implantology, Tokyo Dental College, Chiba, Japan \\ ${ }^{4}$ Japan Institute for Advanced Dentistry, Tokyo, Japan \\ ${ }^{5}$ Department of Pharmacology, Tokyo Dental College, Tokyo, Japan \\ Email: ^tamiura@tdc.ac.jp
}

How to cite this paper: Miura, T., Egawa, M., Ito, T., Eguro, T., Tanabe, K. and Yoshinari, M. (2017) Debridement Effect on Periodontal Pathogen Porphyromonas gingivalis Cultured on Titanium by Application of Atmospheric-Pressure Plasma. J. Biomedical Science and Engineering, 10, 51-59.

https://doi.org/10.4236/jbise.2017.102006

Received: January 9, 2017

Accepted: February 14, 2017

Published: February 17, 2017

Copyright (๑) 2017 by authors and Scientific Research Publishing Inc. This work is licensed under the Creative Commons Attribution International License (CC BY 4.0).

http://creativecommons.org/licenses/by/4.0/ (c)

\begin{abstract}
The debridement treatments of dental implants are very important in longterm maintenance after implant placement in a patient. Deposition of periodontal pathogens around the implant surface has a high risk of causing periimplantitis. The aim of this study was to evaluate the extent of elimination of Porphyromonas gingivalis, known as representative periodontopathic bacteria, from titanium, which has been the main material used for dental implants. Assuming that the debridement processing of dental implants removes periodontal bacteria, one of the methods for removing bacteria deposited on titanium is considered to be plasma irradiation. Irradiation with atmosphericpressure plasma was carried out against periodontopathic bacteria cultured and deposited on the surface of a titanium disk. After the plasma irradiation, the reduction of the number of bacteria re-cultured for 24 hours was evaluated. The number of viable bacteria on the titanium surface was estimated by an ATP-bioluminescent assay. Viable cells after the plasma irradiation were reduced to $1.5 \%$ or less compared to the untreated group. As one of the methods of debridement in general dental treatments, atmospheric-pressure plasma has proved to be an effective method to remove adverse prognostic factors in dental patients.
\end{abstract}

\section{Keywords}

Porphyromonas gingivalis, Atmospheric-Pressure Plasma, Debridement, Peri-Implantitis, Titanium 


\section{Introduction}

Titanium is the most popular material for oral and orthopedicbone implants [1] [2]. The advantages of its mechanical properties and biocompatibility including osseointegration capability with human tissues are the reason for its wide use in the world [3] [4] [5] [6]. Due to the adherence of periodontopathic bacteria, however, there are infection problems associated with titanium implant abutments and fixtures [7] [8] [9].

Peri-implantitis is defined as an inflammatory process affecting the function of tissues around an osseointegrated implant, resulting in loss of supporting bone [10]. Peri-implant inflammation is thought to occur under various conditions, such as the degradation of corrosion resistance, contamination on the implant surface, and implant overloading causing peri-implant bone resorption, interacting with each other.

Although multiple factors can contribute to implant failure, an increasing number of studies point to the detrimental effect of anaerobic plaque bacteria on peri-implant tissue health [11]. Studies have shown similarities in the microflora from implant or tooth sites [12] [13] [14] [15]. High levels of periodontopathic bacteria including Porphyromonas gingivalis are said to be one of the major etiologic factors in human periodontitis [16] [17]. These pathogens are frequently detected in peri-implantitis sites as well [18]. In an earlier in vitro study, the initial attachment of oral bacteria on titanium surfaces was investigated [19]. The results showed that comparatively large amounts of $P$. gingivalis and other periodontopathogens adhered to titanium, even with a polished surface. These findings indicate that there is a considerable risk of adhesion by periodontopathic bacteria to titanium implants.

The procedure of debridement generally aims to remove plaque accumulated inside the periodontal pocket by using manual equipment [20] [21] or ultrasonic waves [22]. In this study, revolutionary physicochemical methods, such as coldplasma treatment, are the reported methods used in attempts to eliminate periodontopathic bacterial layers deposited on the titanium surface. Atmosphericpressure plasma treatment is the usual method of surface modification, which is an effective means on the material surface for changing the element composition, surface wettability, and surface physicochemistry [23] [24]. The short operating time holds the potential for chair-side application for dental treatment. The effect of eradication of periodontopathic bacteria by plasma irradiation was compared with that by chemical agents.

The aim of this study was to consider the debridement effect by applied at mospheric-pressure plasma on selected periodontopathic bacteria cultured on titanium.

\section{Materials and Methods}

\subsection{Specimen Preparation}

Commercial pure titanium (Ti, JIS Grade 2, Tokyo Titanium, Saitama, Japan) disks that were $13 \mathrm{~mm}$ in diameter and $1 \mathrm{~mm}$ in thickness were used. The Ti 
disks were subjected to the sandblasting and acid-etching treatment described below. The disks were perpendicularly sandblasted on both sides from a distance of $10 \mathrm{~mm}$ with $150-\mu \mathrm{m}$ alumina particles (White morundum, Showa Denko, Tokyo, Japan) at an air pressure of 0.4 MPa by a sandblaster (330750, JELENKO Whirlwind, Morrisville, USA). Subsequently, the sandblasted Ti disks were etched with a mixture of $36 \%$ hydrochloric acid $(\mathrm{HCl})$ and $96 \%$ sulfuric acid $\left(\mathrm{H}_{2} \mathrm{SO}_{4}\right)$ for 3 minutes at $70^{\circ} \mathrm{C}$ [25]. Before use in experiments, all specimens were ultrasonically cleaned with acetone, ethanol, and distilled water for $10 \mathrm{mi}$ nutes, followed by sterilization in an autoclave for 15 minutes at $121^{\circ} \mathrm{C}(200$ $\mathrm{kPa}$ ). All specimens were aseptically stored in desiccators for 1 week before use.

\subsection{Bacteria and Culture Conditions}

For plate cultures, the bacteria tested in this study were grown on plates containing Tryptic soy agar (Becton Dickinson and Company, Sparks, MD, USA), which ingredients per liter were pancreatic digest of casein ( $15 \mathrm{~g})$, papaic digest of soybean ( $5 \mathrm{~g}$ ), sodium chloride (5 g), and agar ( $15 \mathrm{~g}$ ), supplemented with $10 \%$ defibrinated horse blood, hemin $\left(5 \mathrm{~g} \cdot \mathrm{L}^{-1}\right)$, and menadione $\left(0.5 \mathrm{~g} \cdot \mathrm{L}^{-1}\right)$. Preculture was performed in an anaerobic chamber $\left(\mathrm{N}_{2}: 80 \%, \mathrm{H}_{2}: 10 \%, \mathrm{CO}_{2}: 10 \%\right)$ at $37^{\circ} \mathrm{C}$ for 4 to 7 days. For liquid cultures, P. gingivalis ATCC 33277 (ATCC, American Type Culture Collection, Manassas, VA, USA) was cultured in Trypticase soy broth (30 g.L $\mathrm{L}^{-1}$; Becton Dickinson and Company, Sparks, MD, USA) supplemented with hemin (5 g. $\mathrm{L}^{-1}$; Sigma Chemical Co., St Louis, MO, USA) and menadione (0.5 g. $\mathrm{L}^{-1}$; Wako Pure Chemical Industries, Osaka, Japan). The precultured colony was inoculated into a liquid broth and incubated for 2 to 4 days under the conditions described above. Before viable bacterial cell count measurement, $100 \mu \mathrm{L}$ of the above liquid culture was inoculated into $1 \mathrm{~mL}$ of a fresh liquid broth. After bacterial cultivation in anaerobic conditions at $37^{\circ} \mathrm{C}$ continued for a further 1 hour, each $200 \mu \mathrm{L}$ aliquot of bacterial fluid was placed on a titanium disk to start culturing for 1 hour under the liquid culture conditions described above. After one more hour of cultivation, specimens with the bacterial fluid were removed from the anaerobic chamber just before a decontamination operation, the fluid was wiped off using sterile gauze, and then the specimens were irradiated by atmospheric-pressure plasma. After plasma irradiation was applied over a titanium disk, another $200 \mu \mathrm{L}$ aliquot of fresh bacterial fluid was put as a replacement on the titanium disk, and the specimens were cultured for 24 hours in anaerobic conditions at $37^{\circ} \mathrm{C}$ as described above.

\subsection{Physical Disinfection by Plasma Irradiation of Titanium Contaminated with Bacteria}

Atmospheric-pressure plasma treatment was performed using a plasma-surface modification apparatus (NJZ-2820, Nagano Japan Radio, Nagano, Japan) at room temperature for 10 to 20 seconds. This operation time was determined from the time required for the plasma flare to sufficiently scan the entire titanium surface. Furthermore, the irradiation position of the apparatus was de- 
cided such that the flare would hit the bacterial layer on the titanium surface. Two distances $(6 \mathrm{~mm}$ and $8 \mathrm{~mm}$ ) from the titanium surface were examined. To determine the optimal irradiation time of plasma, experiments were also conducted under two different conditions (10 s and $20 \mathrm{~s}$ ).

\subsection{Chemical Disinfection of Titanium Contaminated with Bacteria}

The following two kinds of chemical disinfectants are commonly used in dental treatments, and they were examined in comparison with the plasma treatment. Titanium disks were immersed for 2 minutes in the final 0.05\% Hibitane aqueous solution (Sumitomo Dainippon Pharma Co., Ltd., Tokyo, Japan), whose main component is chlorhexidine gluconate, a disinfectant used for surgery. Other disks were immersed for 2 minutes in $10 \% \mathrm{NaOCl}$ (Wako, Osaka, Japan), used as a chlorine-based disinfectant, followed by chloride washing with sterile water.

\subsection{Viable Bacterial Cell Count}

The number of bacteria cultivated over the disk surface was estimated by an ATP-bioluminescent assay using a commercial kit (BacTiter-Glo Microbial Cell Viability Assay kit, Promega, Madison, WI, USA). After 24 hours of incubation with bacteria in an anaerobic condition at $37^{\circ} \mathrm{C}$ described above, all of the bacterial fluids on the disks were recovered in individual plastic tubes, and the disks were washed with an equal volume $(200 \mu \mathrm{L})$ of BacTiter-Glo reagent to remove cells bound to the titanium surface. All of the washed solution was added to the fluid recovered just before and they were briefly mixed; then, ATP activity in the solution was measured using an auto lumicounter (Model 1422EX, Microtec, Funabashi, Japan), and the relative luminescence was determined. In our recent experiments, a standard curve of ATP activity versus colony-forming unit (CFU) obtained by traditional plating methods was established for the periodontopathic bacterium. According to our previous paper, this relationship was very reproducible within the CFU range of $1 \times 10^{5}$ to $1 \times 10^{8}$ [26]. All assays were performed using triplicate samples of each material in at least two different experiments.

\subsection{Statistical Analysis}

All data are expressed as the mean \pm standard deviation (SD). Comparisons between multiple groups were done using one-way or two-way ANOVA followed by a post hoc Tukey's multiple comparisons test. All data were analyzed using Prism 6.0 (GraphPad Software, CA, USA) for Windows. P values less than 0.05 were considered statistically significant.

\section{Results and Discussion}

\subsection{Proliferative Ability of Antimicrobial Bacteria That Were Exposed to Aerobic Conditions}

In order to investigate the viable bacterial count of anaerobic bacteria, they need 
to be exposed to oxygen several times during cultivation for convenience in experimental operations. Therefore, resistance to oxygen was first examined when the bacteria were exposed to oxygen.

Precultured $P$. gingivalis was taken out from an anaerobic box and exposed to an aerobic atmosphere for 5 to 10 minutes. After being cultured again under anaerobic conditions for 24 hours, the number of viable bacterial cells was counted. In the case of aerobic exposure for 5 minutes, $95.9 \%$ viable cells remained; in the case of aerobic exposure for 10 minutes, $95.3 \%$ viable cells remained. Therefore, when cultivated again for 24 hours immediately after the bacterial fluids were exposed to an aerobic atmosphere for up to 10 minutes, it was found that the reduction of the viable cell count subsided to within $5 \%$ or less (Figure 1). This reduction rate seems to be sufficient not to disturb the examination of the debridement effect in this study since the exposure time in experimental operations is 10 minutes or less.

\subsection{Debridement Effect on the Periodontal Pathogen Porphyromonas gingivalis by the Application of Atmospheric-Pressure Plasma Treatment}

In order to maximize the debridement effect by plasma irradiation, the influence of operating conditions with regard to irradiation distance and time on cell reduction was investigated. Two distances $(6 \mathrm{~mm}$ and $8 \mathrm{~mm}$ ) between the titanium disk and plasma flare were examined. The plasma irradiation time against the periodontopathic bacteria cultured on titanium was also investigated, with two durations tried (10 s and $20 \mathrm{~s}$ ). With respect to the irradiation distance, both applied conditions well reduced the viable cell count of the bacteria. All tested groups brought a significantly greater reduction of viable cells than the control group $(p<0.001)$. Figure 2 shows that the closer the distance, the higher the debridement effect. The effect of eliminating the bacteria was significantly higher when the distance between the disk and flare was closer, when plasma irradiation was performed on the titanium surface for either 10 or 20 seconds $(p<$ $0.001)$. In the experimental groups with the distance of $6 \mathrm{~mm}$, it was found that the longer the irradiation time, the higher the debridement effect $(p<0.001)$. Finally, in the conditions where the plasma flare distance was $6 \mathrm{~mm}$ and the irradiation time was 20 seconds $(6 \mathrm{~mm} / 20 \mathrm{~s})$, bactericidal debridement was the most effective.

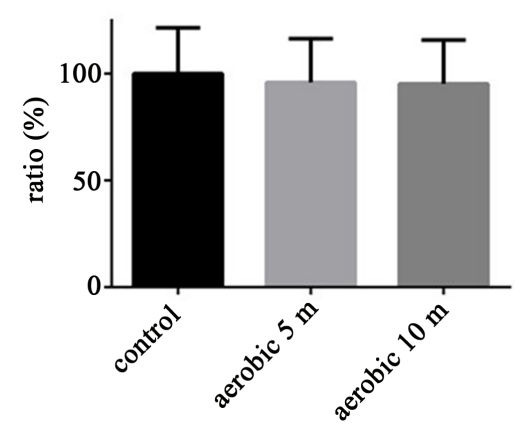

Figure 1. Changes in viable cell count when bacteria are exposed to aerobic conditions. 
Figure 3 shows results of the bacteriostatic effect of $P$. gingivalis whose biofilm deposited on the titanium surface was irradiated by atmospheric-pressure plasma or washed with chemical disinfectants. The viable cell count after the plasma irradiation decreased to $0.13 \% \pm 0.011 \%$. On the other hand, the count after cleaning by Hibitane decreased to $2.3 \% \pm 0.07 \%$. The count after cleaning by $\mathrm{NaOCl}$ decreased to $0.10 \% \pm 0.003 \%$. The bactericidal effect of plasma was greater than that of cleaning by Hibitane $(p<0.001)$. The physicochemical debridement had the same effect as cleaning by sodium hypochlorite. Against the untreated biofilm, the number of viable bacteria on the surface of titanium after the manipulations tested in this study was significantly reduced to $2.3 \%$ or less $(p<0.001)$.

It is the ultimate goal of surgery for embedding dental implants to provide long-term oral function in a biologically good condition. In this study, dental

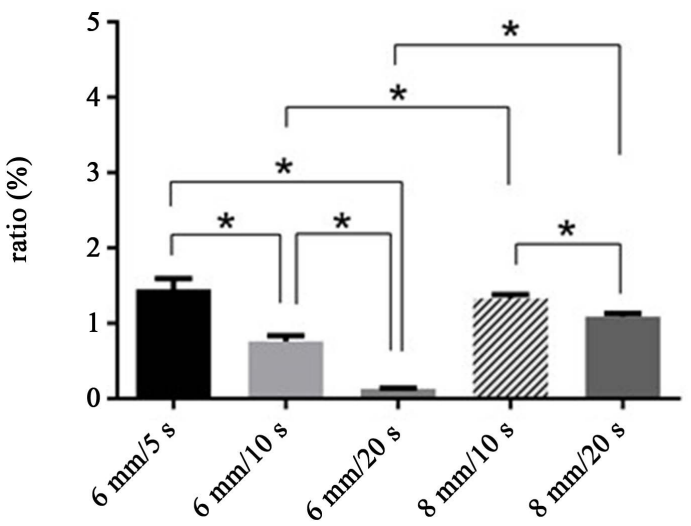

Figure 2. Debridement effect by application of atmospheric-pressure plasma. The optimal distance between flare and disk and the optimal irradiation time were examined. Two distances $(6 \mathrm{~mm}$ and $8 \mathrm{~mm}$ ) from the titanium surface were examined. Consideration was given to irradiation time, with two durations tried (10 s and $20 \mathrm{~s}$ ). The standard deviation is expressed by the bar. Asterisks indicate $p$-values that were considered to be statistically significant $\left({ }^{*}: p<0.001\right)$.

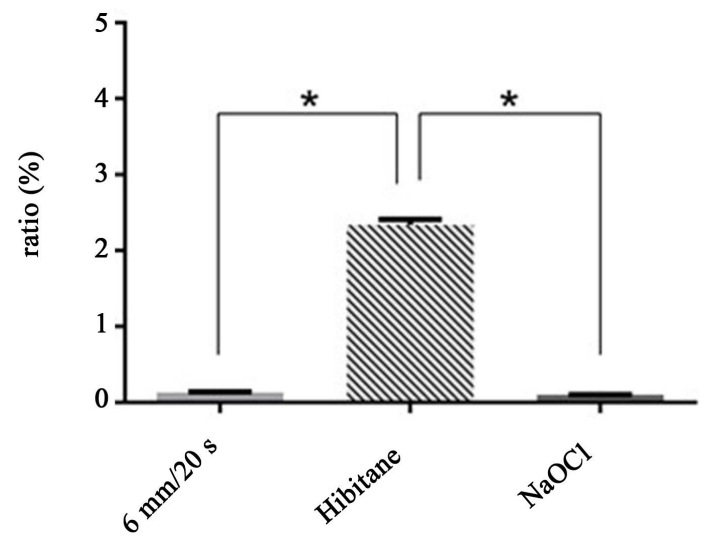

Figure 3. Comparison of debridement effect between atmospheric-pressure plasma and chemical disinfectants. $6 \mathrm{~mm} / 20 \mathrm{~s}$ : plasma irradiation, Hibitane (0.05\% Hibitane), $\mathrm{NaOCl}$ $(10 \%)$. The standard deviation is expressed by the bar. Asterisks indicate $p$-values that were considered to be statistically significant $\left({ }^{*}: p<0.001\right)$. 
debridement by atmospheric-pressure plasma irradiation has shown the potential for clinical application as an effective method to reduce the prevalence of implant periodontitis.

\section{Acknowledgements}

This work was supported by a Grant-in-Aid for Scientific Research (JSPS KAKENHI Grant Number JP16K11635) from the Japan Society for the Promotion of Science.

\section{References}

[1] Breine, U. and Brånemark, P.I. (1980) Reconstruction of Alveolar Jaw Bone. An Experimental and Clinical Study of Immediate and Preformed Autologous Bone Grafts in Combination with Osseointegrated Implants. Scandinavian Journal of Plastic and Reconstructive Surgery, 14, 23-48.

https://doi.org/10.3109/02844318009105733

[2] Williams, D.F. (1977) Titanium as a Metal for Implantation. Part 1: Physical Properties. Journal of Medical Engineering \& Technology, 1, 195-198. https://doi.org/10.3109/03091907709160643

[3] Shastry, C.V. and Goldberg, A.J. (1983) The Influence of Drawing Parameters on the Mechanical Properties of Two Beta-Titanium Alloys. Journal of Dental Research, 62, 1092-1097. https://doi.org/10.1177/00220345830620101901

[4] Mezger, P.R. and Creugers, N.H. (1992) Titanium Nitride Coatings in Clinical Dentistry. Journal of Dentistry, 20, 342-344. https://doi.org/10.1016/0300-5712(92)90021-4

[5] Neo, T.K., Chai, J., Gilbert, J.L., Wozniak, W.T. and Engelman, M.J. (1996) Mechanical Properties of Titanium Connectors. International Journal of Prosthodontics, 9, 379-393.

[6] Katakura, A., Shibahara, T., Noma, H. and Yoshinari, M. (2004) Material Analysis of AO Plate Fracture Cases. Journal of Oral and Maxillofacial Surgery, 62, 348-352. https://doi.org/10.1016/j.joms.2003.05.009

[7] Markiewicz, M.R., Nishiyama, K., Yago, K., Okada, M., Asanami, S., Yoshinari, M., Hirayama, M., Margarone, J.E. and Chuang, S.K. (2007) Draining Orocutaneous Fistula Associated with a Failing Subperiosteal Implant: Report of a Case. Journal of Oral Implantology, 33, 347-352. https://doi.org/10.1563/1548-1336(2007)33[347:DOFAWA]2.0.CO;2

[8] Rosenberg, E.S., Torosian, J.P. and Slots, J. (1991) Microbial Differences in 2 Clinically Distinct Types of Failures of Osseointegrated Implants. Clinical Oral Implants Research, 2, 135-144. https://doi.org/10.1034/j.1600-0501.1991.020306.x

[9] Aoki, M., Takanashi, K., Matsukubo, T., Yajima, Y., Okuda, K., Sato, T. and Ishihara, K. (2012) Transmission of Periodontopathic Bacteria from Natural Teeth to Implants. Clinical Implant Dentistry and Related Research, 14, 406-411. https://doi.org/10.1111/j.1708-8208.2009.00260.x

[10] Albrektsson, T. and Isidor, F. (1994) Consensus Report of Session IV. In: Lang, N.P. and Karring, T., Eds., Proceedings of the First European Workshop on Periodontology, Quintessence Publishing, London, 365-369.

[11] Mombelli, A. and Lang, N.P. (1998) The Diagnosis and Treatment of Peri-Implantitis. Periodontology 2000, 17, 63-76.

https://doi.org/10.1111/j.1600-0757.1998.tb00124.x 
[12] Aspe, P., Ellen, R.P., Overall, C.M. and Zarb, G.A. (1989) Microbiota and Crevicular Fluid Collagenase Activity in the Osseointegrated Dental Implant Sulcus: A Comparison of Sites in Edentulous and Partially Edentulous Patients. Journal of Periodontal Research, 24, 96-105. https://doi.org/10.1111/j.1600-0765.1989.tb00863.x

[13] Leonhardt, A., Gröndahl, K., Bergström, C. and Lekholm, U. (2002) Long-Term Follow-Up of Osseointegrated Titanium Implants Using Clinical, Radiographic and Microbiological Parameters. Clinical Oral Implants Research, 2, 127-132. https://doi.org/10.1034/j.1600-0501.2002.130202.x

[14] Sumida, S., Ishihara, K., Kishi, M. and Okuda, K. (2002) Transmission of Periodontal Disease-Associated Bacteria from Teeth to Osseointegrated Implant Regions. The International Journal of Oral \& Maxillofacial Implants, 17, 696-702.

[15] Gerber, J., Wenaweser, D., Heitz-Mayfield, L., Lang, N.P. and Persson, G.R. (2006) Comparison of Bacterial Plaque Samples from Titanium Implant and Tooth Surfaces by Different Methods. Clinical Oral Implants Research, 17, 1-7. https://doi.org/10.1111/j.1600-0501.2005.01197.x

[16] Slots, J., Bragd, L., Wikström, M. and Dahlen, G. (1986) The Occurrence of Actinobacillus actinomycetemcomitans, Bacteroides Gingivalis and Bacteroides intermedius in Destructive Periodontal Disease in Adults. Journal of Clinical Periodontology, 13, 570-577. https://doi.org/10.1111/j.1600-051X.1986.tb00849.x

[17] Teles, R.P., Haffajee, A.D. and Socransky, S.S. (2006) Microbiological Goals of Periodontal Therapy. Periodontology 2000, 42, 180-218. https://doi.org/10.1111/j.1600-0757.2006.00192.x

[18] Quirynen, M., Vogels, R., Pauwels, M., Haffajee, A.D., Socransky, S.S., Uzel, N.G. and van Steenberghe, D. (2005) Initial Subgingival Colonization of Pristine Pockets. Journal of Dental Research, 84, 340-344. https://doi.org/10.1177/154405910508400409

[19] Yoshinari, M., Oda, Y., Kato, T., Okuda, K. and Hirayama, A. (2000) Influence of Surface Modifications to Titanium on Oral Bacterial Adhesion in Vitro. Journal of Biomedical Materials Research, 52, 388-394. https://doi.org/10.1002/1097-4636(200011)52:2<388::AID-JBM20>3.0.CO;2-E

[20] Greenstein, G. (2000) Nonsurgical Periodontal Therapy in 2000: A Literature Review. The Journal of the American Dental Association, 131, 1580-1592. https://doi.org/10.14219/jada.archive.2000.0087

[21] Roncati, M. and Gariffo, A. (2014) Systematic Review of the Adjunctive UsE of Diode and Nd: YAG Lasers for Nonsurgical Periodontal Instrumentation. Photomedicine and Laser Surgery, 32, 186-197. https://doi.org/10.1089/pho.2013.3695

[22] Ratka-Krüger, P., Mahl, D., Deimling, D., Mönting, J.S., Jachmann, I., Al-Machot, E., Sculean, A., Berakdar, M., Jervøe-Storm, P.M. and Braun, A. (2012) Er: YAG Laser Treatment in Supportive Periodontal Therapy. Journal of Clinical Periodontology, 39, 483-489. https://doi.org/10.1111/j.1600-051X.2012.01857.x

[23] Matsuzaki, H., Yamamoto, H., Shibata, K., Komiyama, Y. and Yoshinari, M. (2014) Effect of Atmospheric Pressure Plasma Treatment on Surface Properties of Commercial Titanium Implants. Journal of Japanese Society of Oral Implantology, 27, 528-540.

[24] Miyake, N., Miura, T., Tanabe, K., Hisanaga, R., Yamashita, S., Sato, T. and Yoshinari, M. (2016) Effect of Physicochemical Surface Modifications on Bovine Serum Albumin Adsorption to Tetragonal Zirconia Polycrystal in Vitro through the Change of the Zeta Potential. Journal of Oleo Science, 65, 1003-1010. https://doi.org/10.5650/jos.ess16053

[25] Hirano, T., Sasaki, H., Honma, S., Furuya, Y., Miura, T., Yajima, Y. and Yoshinari, 
M. (2015) Proliferation and Osteogenic Differentiation of Human Mesenchymal Stem Cells on Zirconia and Titanium with Different Surface Topography. Dental Materials Journal, 34, 872-880. https://doi.org/10.4012/dmj.2015-129

[26] Egawa, M., Miura, T., Kato, T., Saito, A. and Yoshinari, M. (2013) In Vitro Adherence of Periodontopathic Bacteria to Zirconia and Titanium Surfaces. Dental Materials Journal, 32, 101-106. https://doi.org/10.4012/dmj.2012-156

Submit or recommend next manuscript to SCIRP and we will provide best service for you:

Accepting pre-submission inquiries through Email, Facebook, LinkedIn, Twitter, etc. A wide selection of journals (inclusive of 9 subjects, more than 200 journals)

Providing 24-hour high-quality service

User-friendly online submission system

Fair and swift peer-review system

Efficient typesetting and proofreading procedure

Display of the result of downloads and visits, as well as the number of cited articles Maximum dissemination of your research work

Submit your manuscript at: http://papersubmission.scirp.org/

Or contact jbise@scirp.org 